\title{
Measuring the waste footprint of cities in Japan: an interregional waste input-output analysis
}

\author{
Makiko Tsukui ${ }^{*}$, Shigemi Kagawa ${ }^{2}$ and Yasushi Kondo ${ }^{3}$
}

*Correspondence:
makiko@tiu.ac.jp
${ }^{1}$ Faculty of Commerce, Tokyo
International University,
1-13-1, Matoba-kita,
Kawagoe, Saitama 350-1197,
Japan
Full list of author information
is available at the end of the
article

*Correspondence

makiko@tiu.ac.jp

International University,

1-13-1, Matoba-kita

Japan article

\begin{abstract}
Metropolitan regions, which are typically planned without considering aspects related to sustainability, tend to depend on neighboring regions for their waste treatment, particularly for the disposal of solid waste in landfills. The repercussion effects of consumption in metropolitan regions may bring about economic benefits. However, quantitative assessments of the interregional relationships between the metropolitan areas and the other regions are necessary in order to clarify whether the undesirable environmental loads incurred by the surrounding regions are outweighed by economic benefits. In this study, we clarified the repercussion effects of consumption by metropolitan residents on production and environmental loads by examining the utilization of landfill sites in these other regions using interregional waste input-output (IRWIO) analysis. Specifically, we investigated the effects of consumption activities in Tokyo, and compiled an IRWIO table for Tokyo in the year 2000. Using this table, we then estimated the effects of landfill utilization in Tokyo and other regions, as well as the associated induced economic and environmental impacts. The results showed that consumption in Tokyo induced limited economic benefits and large-scale utilization of landfills in other regions. Although consumption by Tokyo residents induced an increase in the recycling of municipal solid waste (MSW), thus reducing the amount of waste to be treated in other regions, the total amount of induced landfill volume was 1.7 million cubic meter, which is 2.4 times greater than that of Tokyo. The results quantitatively clarified the repercussion effects associated with consumption by residents in metropolitan areas and illustrated the importance of sustainable waste management to stakeholders, particularly those in metropolitan regions.
\end{abstract}

\section{Background}

As the consumption activities in metropolitan regions are typically larger than those of rural regions, so too is consumer responsibility of metropolitan regions larger than that in rural regions. From the late 1990s to the early 2000s, numerous studies examined consumer responsibility and the associated environmental loads (Hertwich 2011; Nijdam et al. 2005; Wiedmann et al. 2006, 2013; Wiedmann 2009), especially those associated with carbon dioxide (Lenzen and Murray 2001; Peters and Hertwich 2006a, b, 2008; Wiedmann et al. 2007; McGregor et al. 2008; Peters 2008; Weber and Matthews 2007, 2008; Wilting and Vringer 2009), water consumption (Cazcarro et al. 2013; Daniels

(C) 2015 Tsukui et al. This article is distributed under the terms of the Creative Commons Attribution 4.0 International License (http:// creativecommons.org/licenses/by/4.0/), which permits unrestricted use, distribution, and reproduction in any medium, provided you give appropriate credit to the original author(s) and the source, provide a link to the Creative Commons license, and indicate if changes were made. 
et al. 2011; Feng et al. 2012; Guan and Hubacek 2007; Lenzen 2009; López-Morales and Duchin 2011), land consumption (Bicknell et al. 1998; Wilting and Vringer 2009), and loss of biodiversity (Lenzen et al. 2012). Although most of these studies examined these aspects at a global level between countries, the consumer responsibility associated with these consumption activities at a local level, such as consumption by the cities and country regions concerned, has received comparatively little attention (Minx et al. 2009). However, the cities and regions within a country have their own local environmental policies, and these policies play an important role in dealing with the problems associated with waste treatment. Although many cities in developed countries, such as Stockholm and Adelaide, are attempting to become "zero waste" cities (Zaman and Lehmann 2011), cities such as Tokyo are confronted with serious problems related to sharing responsibilities between local regions.

Tokyo is one of the largest metropolitan regions in the world with a population exceeding 12 million people (Statistics Bureau of Ministry of Internal Affairs and Communications (MIC) Japan 2014), and it is both directly and indirectly responsible for serious negative environmental impacts in regions outside Tokyo.

The direct environmental impacts are attributable to the transport of wastes from Tokyo to other regions. In 2007, $81 \%$ of the waste generated by Tokyo was exported to landfill sites in other regions (Bureau of Environment (BoE) 2012; Tokyo Metropolitan Government (TMG) 2011, 2012). A simple solution to this problem would be to construct a final disposal facility in Tokyo, but the high population density and land prices in the city have precluded any provisions for such a facility in the waste treatment plan for Tokyo (TMG 2008). The population density of Tokyo in 2011 was 6029 people $/ \mathrm{km}^{2}$, which was markedly higher than the 343 people $/ \mathrm{km}^{2}$ average for Japan as a whole. In addition, the land prices in Tokyo in 2011 were also the highest in Japan, averaging $208,900 \mathrm{yen} / \mathrm{m}^{2}$ for industrial land. Although two new landfill sites were constructed in Tokyo in 2004, the absence of any plans to construct additional landfill sites in the future (TMG 2008) means that direct exports of waste generated in Tokyo will continue, and likely increase, in the future. Using a choice experiment, Sasao (2004) assessed public opinion regarding the construction of landfills in a rural region in northern Japan. He found that residents were considerably more opposed to accept industrial waste from Tokyo than they were to landfilling their own municipal solid waste (MSW). The problem of waste treatment, especially landfilling, is a very contentious issue and source of confrontation between Tokyo and rural regions.

Since these direct effects are easy to recognize, they can be addressed directly through cooperation between the local governments involved. However, the indirect effects that are responsible for consumption in metropolitan regions and that are related to the problem of consumer responsibility are both difficult to recognize and overlooked as problems. The average income of Tokyo residents is approximately $15 \%$ higher than that of residents elsewhere in Japan. Similarly, total consumption by Tokyo residents, which is associated with increases in waste generation and environmental loads, is $12 \%$ higher than the average per capita consumption of other regions. Although consumption in Tokyo stimulates industrial activity in other regions, it also increases the amount of industrial waste produced by those regions. Since these wastes are treated outside of Tokyo, Tokyo indirectly exports industrial waste and consumes the landfill sites of other 
regions. To the best of our knowledge, however, the effect of consumption by Tokyo residents has not yet been accurately quantified. As a result, most Tokyo residents are unaware of how much of their waste is transported to, and disposed of in, other regions, and how their lifestyles affect waste generation, waste treatment, and landfill utilization in those regions. To prepare a basis for a discussion of these topics, it is, therefore, very important to consider the usage and development of landfill sites within an interregional context.

From the late 1990s to the early 2000s, numerous studies examined the consumer responsibility of environmental loads. Bicknell et al. (1998) calculated the ecological footprint of New Zealand using an IO analysis. Lenzen and Murray (2001) estimated land use and greenhouse gas emissions using a single-region IO analysis. Nijdam et al. (2005) employed an IO model to investigate the environmental loads associated with Dutch private consumption considering the technology differences among three regions (i.e., The Netherlands, OECD and non-OECD countries). From the early 2000s, investigators interested in the consumer responsibility associated with environmental loads began to recognize the importance of environmental loads and the extent to which they are embodied in trade. Indeed, it was this realization that prompted the development of the multi-regional input-output (MRIO) approach. Lenzen et al. (2004) estimated the consumer responsibility associated with greenhouse gas emissions (GHG) embodied in trade. In addition, they also applied the IO approach to trade and found that MRIO models were more accurate than single-region IO models. Peter and Hertwich (2006a, b) applied the MRIO model developed by Lenzen et al. (2004) to examine the pollution embodied in Norwegian trade, considering the regional differences in the production technologies of different countries. Wiedmann et al. (2006) estimated the repercussion effects of household expenditure using existing ecological footprint data and a supply-and-use table for the United Kingdom (UK). All of these studies contributed to the development of the MRIO framework. Weber and Matthews $(2007,2008)$ used an MRIO model to analyze the environmental effects and carbon footprint of households in the United States and its seven largest trading partners. Turner et al. (2007) proposed that the MRIO accounting approach was the most appropriate method for estimating ecological footprints. McGregor et al. (2008) applied a two-region IO framework to enumerate the $\mathrm{CO}_{2}$ pollution content of interregional trade flows between Scotland and the rest of the UK in their provisional investigation. Peters (2008) developed a multi-regional input-output analysis (MRIOA) that considered carbon leakage for the consumptionbased National Emission Inventory initiative and compared it with emissions embodied in bilateral trade. Wilting and Vringer (2009) applied an MRIO model to 12 world regions to compare the outcomes of a producers-and-consumers approach for considering GHG emissions and land use; for GHG emissions, they evaluated 87 countries and regions. Daniels et al. (2011) proposed that the process-based methods of MRIOA were well suited for estimating water footprints and clarifying the components of the virtual water supply chain. Lenzen et al. (2012) used threatened animal species data to generate an MRIOT to evaluate the biodiversity footprint of 187 countries. Wiedmann et al. (2013) presented a time series analysis of the material footprint, which is a consumption-based indicator of resource use, using an MRIOA for 186 countries. 
As stated in the beginning of the introduction, most of the aforementioned studies considered these various relationships at the country level; however, some investigators have employed an MRIOA to evaluate consumer responsibility between different regions within a country. Guan and Hubacek (2007) investigated virtual water flow in China using a two-region MRIOA for 40 industrial sectors. Yi et al. (2007) developed an expanded interregional IO method (EIOM) based on the life cycle assessment (LCA) methodology to evaluate four environmental burdens $\left(\mathrm{CO}_{2}, \mathrm{NO}_{\mathrm{X}}, \mathrm{SO}_{\mathrm{X}}\right.$ and SPM) in the 47 prefectures of Japan. In a case study of the Australian state of Victoria using an MRIOA, Lenzen (2009) enumerated virtual water flows in eight regions, each with 344 sectors. Minx et al. (2009) provided a thorough overview of IO applications for analyzing carbon footprints, including the regional and local carbon footprints of 434 local authorities in the UK. Feng et al. (2012) investigated supply chain effects and regional virtual water flows using an MRIOA of three river reaches in the Yellow River Basin. López-Morales and Duchin (2011) implemented an MRIO model based on the World Trade Model to evaluate policy scenarios for 13 hydro-economic regions. Hasegawa et al. (2011) constructed an MRIOT for the 47 prefectures of Japan to estimate the carbon footprint and carbon leakage. Cazcarro et al. (2013) employed an MRIO approach to estimate the water footprint of 16 regions in Spain, and clarified the interregional and international trade of virtual water.

However, few studies have applied an MRIOA to clarify the various waste issues of local regions. Waste input-output analysis (Nakamura and Kondo 2002, 2009) has been used extensively to measure waste footprints at national and regional levels. Kagawa et al. (2007) and Kagawa and Kondo (2007) produced a multi-regional waste input-output (WIO) table for nine regions in Japan, and investigated the effect of consumption within each region on the other regions for the year 1995. Reynolds et al. (2012) illustrated the theoretical background of a multi-regional WIO analysis model and clarified the difficulties associated with the construction of a multi-regional WIO table for eight Australian regions. Lenzen and Reynolds (2014) and Reynolds et al. (2014) developed waste supply-use tables (WSUTs), which expanded on the WIO framework by incorporating a supply-use table, to analyze economic and waste data in Australia in 20082009. Fry and Lenzen (2014) described a method for constructing a multi-regional WIO framework utilizing Australian waste data; the framework was compiled using the System of Environmental-Economic Accounting (SEEA).

In line with these WIO studies, we constructed a new multi-regional WIO database for Tokyo and the other regions in Japan, and quantified waste generation and landfill consumption induced by final demand in Tokyo and these other regions, respectively. Within the context of the existing body of literature, our study differs from previous studies in that Japan is divided into 47 administrative regions called prefectures, each of which has a local government that promulgates its own environmental and waste treatment policies; the capital of the country, Tokyo, is also a prefecture, and it has the largest economy of all the prefectures. Previous studies on Japan, such as that of Kagawa et al. (2007) and Kagawa and Kondo (2007) employed nine regions. These regions are commonly employed by the Japanese government for the sake of convenience. However, some of the prefectures within these regions are markedly different, both economically and environmentally, from the other prefectures in the same region (Hasegawa et al. 2011; Tsukui and Nakamura 2009; Tsukui 2009). While Kagawa et al. (2007) and Kagawa and Kondo (2007) estimated the 
effect of per capita consumption on the amount of waste to be treated and the landfill volume required, their nine-region WIO table did not facilitate a detailed assessment of the effect of consumption on waste generation in a specific prefecture. Yi et al. (2007) and Hasegawa et al. (2011) investigated environmental loads in the 47 prefectures of Japan, but they did not consider aspects of waste related to environmental loads (e.g., waste generation and landfill volume). To quantitatively clarify the interregional dependence between Tokyo and the other regions in terms of waste treatment, it is considered important to construct an MRIO table and model for the prefectures being considered.

In this study, we quantitatively investigated the direct and indirect economic and environmental effects of consumption induced by Tokyo residents on other regions in Japan using the interregional WIO (IRWIO) approach. This paper is structured as follows. In Sect. 2, we describe the IRWIO model that was employed in this study. We also describe the data that were used to compile the WIO Tokyo 2000 table, and explain how the table was compiled. In Sect. 3, we present the results showing the effect of consumption in Tokyo on landfill utilization in both Tokyo and in the other regions. We also examine the effect of consumption in Tokyo on waste generation, economic activity and greenhouse gas emissions in both Tokyo and in the other regions, within the context of the differences in the economic and waste treatment activities in Tokyo and in the other regions. In Sect. 4, we summarize our findings and propose several topics for future research. We provide the compilation results of the Tokyo 2000 IRWIO table and the detailed results of the direct and indirect effects in Additional file 1.

\section{Methods}

\subsection{An interregional WIO model}

The WIO models developed for regional analysis not only consider the import and export of goods and services, but they also consider the movement of waste and environmental loads. In this study, we employed an interregional WIO model that uses a non-competitive import-type WIO table (Isard 1951; Leontief 1963; Nakamura and Kondo 2002; Kagawa et al. 2007; Kagawa and Kondo 2007).

Table 1 shows the basic structure of the two-region IRWIO table used in this study. Consider an economy such as that shown in Table 1, consisting of industrial sectors, waste treatment sectors, final demand sectors, waste items, and the value added by each sector. $\mathbf{Z}_{\mathbf{I}}^{\text {rs }}$ denotes the transactions of industrial sectors and shows the intermediate input of region $s$ from region $r$. $\mathbf{Z}_{\mathrm{II}}^{\text {rs }}$ denotes the intermediate input of waste treatment sectors in region $s$ from region $r . \mathbf{W}_{\mathbf{I}}^{\text {rs }}$ and $\mathbf{W}_{\mathbf{I I}}^{\text {rs }}$ denote waste generation in region $r$ excluding recycling from industrial sectors in region $s$, and waste generation in region $r$ excluding recycling from waste treatment sectors in region $s$, respectively. Subscripts I and II denote the industrial sectors and waste treatment sectors, respectively. The superscripts denote the region, $r, s \in\{1,2,3\}$, where region 1 represents the metropolitan region, region 2 represents domestic regions other than region 1, and region 3 represents the rest of the world; in the case study we present in Sect. 3, region 1 denotes Tokyo, region 2 denotes the rest of Japan, and region 3 denotes regions other than Japan. The number of industrial sectors is denoted by $n_{x}$ and that of the waste treatment sectors is denoted by $n_{z}$.

f is a vector denoting the row sums of final demand. In region $s$, the final demand sectors are further divided into vectors, $\mathbf{f}_{\mathrm{C}}^{\mathbf{r s}}, \mathbf{f}_{\mathbf{w C}}^{\mathbf{r s}}, \mathbf{f}_{\mathbf{O}}^{\mathbf{r s}}$ and $\mathbf{f}_{\mathbf{w O}}^{\mathbf{r s}}$, which denote consumption 
Table 1 Framework of a two-region interregional waste input-output table

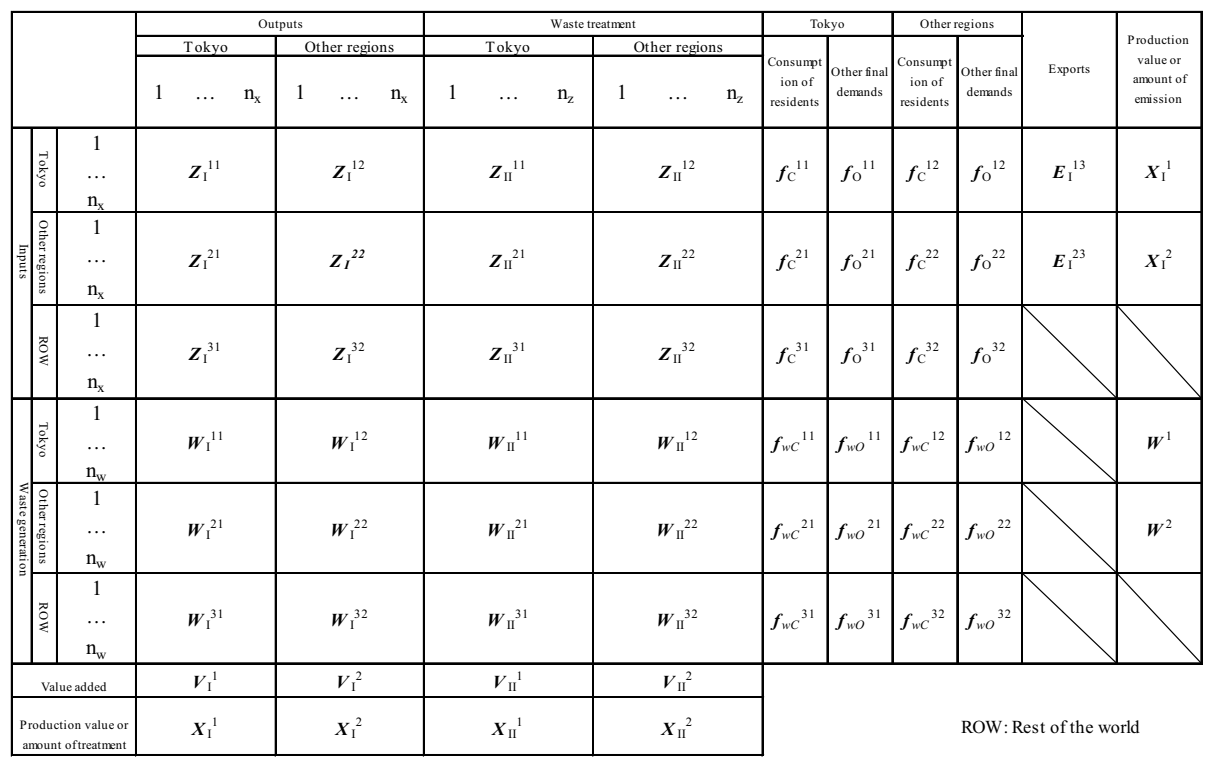

of goods and services of region $r$ by the residents of region $s$, waste generation by the residents of region $s$ that is treated in region $r$, other final demands in region $s$ for goods and services of region $r$, and waste generated in region $s$ by sources other than the residents and treated in region $r$, respectively. The subscript $C$ denotes the consumption of the residents of region $s$, and $\mathrm{O}$ denotes the final demand sector of residents other than residents of region $s$ such as that attributed to visitors and commuters from the other regions, government expenditure, and fixed capital formation. $\mathrm{V}$ is a matrix denoting the value added, and $\mathbf{E}$ is a vector denoting international exports. $\mathbf{W}_{\mathbf{I I}}^{3 \mathbf{s}}$ indicates the international transportation of waste from region $s$.

$\mathbf{A}_{\mathbf{I}, \mathbf{I}}^{\mathrm{rs}}$ denotes the coefficient matrix of intermediate inputs per unit production value from the industrial sectors in region $r$ to the industrial sectors in region $s ; \mathbf{A}_{\mathbf{I}, \mathbf{I I}}^{\mathbf{r s}}$ is the coefficient matrix of intermediate inputs per unit amount of waste generated by the industrial sectors in region $r$ and transferred to the waste treatment sectors in region $s$; $\mathbf{G}_{\text {III, }}^{\mathbf{r s}}$ is the coefficient matrix of waste generation per unit production value from industrial sectors in region $s$ to waste items in region $r$; and $\mathbf{G}_{\mathbf{I I}, \mathbf{I I}}^{\mathbf{r s}}$ is the coefficient matrix of the waste generated by the waste treatment sectors in region $s$ and the waste transferred to the waste treatment sectors in region $r$. These coefficient matrices are defined in Eqs. (1)-(4), which follow Kagawa et al. (2007).

$$
\begin{aligned}
& \mathbf{A}_{\mathbf{I}, \mathbf{I}}^{\mathbf{r s}}=\left(a_{\mathrm{I}, \mathrm{I}}^{r s}(i, j)\right)=\left(\frac{\mathbf{Z}_{\mathbf{I}}^{\mathbf{r s}}(\mathbf{i}, \mathbf{j})}{\mathbf{X}_{\mathbf{I}}^{\mathbf{s}}(\mathbf{j})}\right) \quad\left(i=1, \cdots, n_{\mathbf{X}} ; j=1, \cdots, n_{\mathbf{X}} ; r, s=1,2,3\right) \\
& \mathbf{A}_{\mathbf{I}, \mathbf{I I}}^{\mathbf{r s}}=\left(a_{\mathrm{I}, \mathrm{II}}^{r s}(i, j)\right)=\left(\frac{\mathbf{Z}_{\mathbf{I I}}^{\mathbf{r s}}(\mathbf{i}, \mathbf{j})}{\mathbf{X}_{\mathbf{I I}}^{\mathbf{s}}(\mathbf{j})}\right) \quad\left(i=1, \cdots, n_{\mathbf{X}} ; j=1, \cdots, n_{\mathrm{Z}} ; r, s=1,2,3\right) \\
& \mathbf{G}_{\mathbf{I I}, \mathbf{I}}^{\mathbf{r s}}=\left(g_{\mathrm{II}, \mathbf{I}}^{r s}(i, j)\right)=\left(\frac{\mathbf{W}_{\mathbf{I}}^{\mathbf{r s}}(\mathbf{i}, \mathbf{j})}{\mathbf{X}_{\mathbf{I}}^{\mathbf{s}}(\mathbf{j})}\right) \quad\left(i=1, \cdots, n_{\mathbf{W}} ; j=1, \cdots, n_{\mathbf{X}} ; r, s=1,2,3\right)
\end{aligned}
$$




$$
\mathbf{G}_{\mathrm{II}, \mathrm{II}}^{\mathbf{r s}}=\left(g_{\mathrm{II}, \mathrm{II}}^{r s}(i, j)\right)=\left(\frac{\mathbf{W}_{\mathbf{I I}}^{\mathrm{rs}}(\mathbf{i}, \mathbf{j})}{\mathbf{X}_{\mathbf{I I}}^{\mathbf{s}}(\mathbf{j})}\right) \quad\left(i=1, \cdots, n_{\mathrm{W}} ; j=1, \cdots, n_{\mathrm{Z}} ; r, s=1,2,3\right)
$$

$\mathbf{S}^{r}$ in Eq. (5) is the allocation matrix, which is the ratio of the amount of waste $k$ that is treated by waste treatment activity $i$ in region $r . s(i, j)$ indicates the element of the matrix or vector $x$ of row $i$ and column $j$.

$$
\mathbf{S}^{\mathbf{r}}=\left(s^{r}(i, k)\right) \quad\left(i=1, \cdots, n_{\mathbf{W}} ; j=1, \cdots, n_{\mathbf{Z}} ; r=1,2,3\right)
$$

Using the matrices defined in Eqs. (1)-(5), we defined the coefficient matrix $\overline{\mathbf{A}}$, the vectors of the row sum of final demand $\overline{\mathbf{F}}_{\mathbf{C}}$ and $\overline{\mathbf{F}}_{\mathrm{D}}$, the vector of the row sum of international exports $\overline{\mathbf{E}}$, the vector of the row sum of the production value and waste treatment value $\overline{\mathbf{X}}$ in Eqs. (6)-(9).

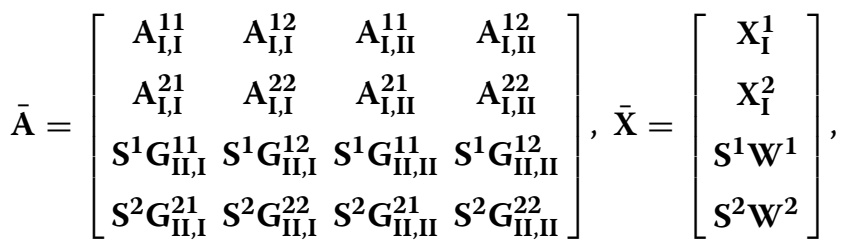

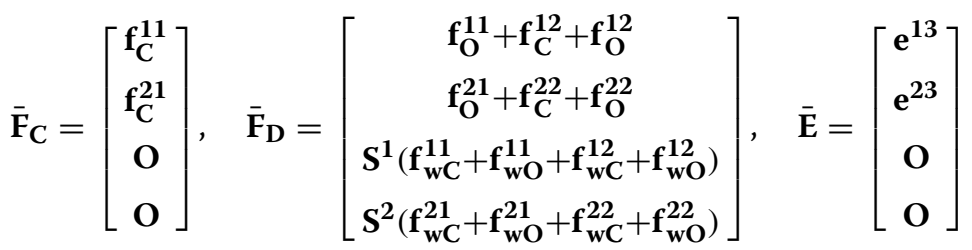

By applying Eqs. (6) and (7), the equilibrium equations can be represented as follows:

$$
\overline{\mathbf{X}}=(\mathbf{I}-\overline{\mathbf{A}})^{-1}\left(\overline{\mathbf{F}}_{\mathbf{C}}+\overline{\mathbf{F}}_{\mathbf{D}}+\overline{\mathbf{E}}\right)
$$

From Eq. (8), as $\overline{\mathbf{F}}_{\mathbf{C}}$ denotes the consumption by Tokyo residents, $\overline{\mathbf{X}}_{\mathbf{C}}$, the vector of the effect of consumption by metropolitan residents, can be obtained as follows:

$$
\overline{\mathbf{X}}_{\mathbf{C}}=(\mathbf{I}-\overline{\mathbf{A}})^{-1} \overline{\mathbf{F}}_{\mathbf{C}}
$$

In this study, we estimated $\overline{\mathbf{X}}_{\mathbf{C}}$ for Tokyo and evaluated the effects of consumption by metropolitan residents on industrial sectors, waste items, waste treatment sectors, and the environmental loads of each sector. The environmental loads can be estimated by multiplying the coefficient matrices by $\overline{\mathbf{X}}_{\mathbf{C}}$.

\subsection{DATA collection and processing for the Tokyo 2000 IRWIO table}

The table was compiled for two regions, i.e., Tokyo and all other regions (i.e., all regions except Tokyo). The table has 197 industrial sectors, 13 waste treatment sectors, 17 final demand sectors, 96 waste items, seven value-added items, and three types of environmental loads (Tsukui 2007a, b, 2008, 2009; Tsukui and Nakamura 2009, Tsukui et al. 2011a, b). Data for the commodity-by-industry, value added-by-industry, and commodity-by-final demand parts were obtained from the 2000 Tokyo interregional input-output table (TMG table, hereafter) (TMG 2007). In Japan, for the purposes of waste treatment, waste is categorized 
into industrial waste and MSW, which can further be categorized into business waste and household waste. The amount of waste generated by industrial sectors and final demand sectors was mainly estimated using statistical data published by Japanese government ministries and agencies (Ministry of Finance 2000; BoE-TMG 2001, 2003; Habara et al. 2002; METI 2002; Ministry of Environment (MOE) of Japan 2003a, b, 2004; Nakamura 2010; Statistics Bureau of the Ministry of Internal Affairs and Communications (MIC) of Japan 2000, 2004). In estimating the waste items generated in Tokyo, we also referred to the information contained in the Clean Association of TOKYO23 (2001). Three environmental load sectors were considered: $\mathrm{CO}_{2}$ emissions, landfill volume, and landfill area. The $\mathrm{CO}_{2}$ emission sector was defined based on the 3EID database (Nansai et al. 2008). Since landfilling is the result of waste treatment activities, the landfill volume and landfill area were grouped with the waste treatment sectors and not with any of the industrial sectors.

The goods and services consumed by the waste treatment sectors, and the waste generated by the waste treatment sectors, were estimated using the method employed for compiling the WIO tables (Nakamura and Kondo 2002; New Energy and Industrial Technology Development Organization (NEDO) 2005). When compiling the Tokyo 2000 IRWIO table, industrial waste and MSW were considered to be treated at different facilities (Tsukui et al. 2011a, b). Based on this assumption, we were able to investigate the effects of industrial waste and MSW. Table 2 shows the waste treatment sectors in the Tokyo 2000 IRWIO table. The activity of the waste treatment sectors was estimated using the model described in Sect. 2 and the engineering sub-model for waste treatment developed by Matsuto (2005), which was also used in the estimation of WIO2000 (Nakamura 2010). To quantify the activities associated with waste transportation, we employed the model developed by Tsukui (2009).

Table 2 Waste treatment sectors in the Tokyo 2000 IRWIO table

\begin{tabular}{ll}
\hline Waste category & Waste treatment sectors \\
\hline MSW & Incineration (continuous type with generator) \\
Incineration (continuous type without generator) \\
Incineration (batch type) \\
Landfill \\
Shredding: bulky textiles \\
Shredding: wooden furniture \\
Shredding: bikes, ovens \\
Shredding: small electric appliances \\
Shredding: TV sets \\
Shredding: refrigerators \\
Shredding: washing machines \\
Shredding: air conditioners \\
Shredding: automobiles \\
Shredding \\
Incineration (continuous type with generator) \\
Incineration (continuous type without generator) \\
Incineration (batch type) \\
Landfill \\
Transportation for intermediate treatment \\
Transportation to landfills \\
\hline
\end{tabular}




\section{Results and discussion}

\subsection{Differences in economic activity between Tokyo and other regions}

The economies of Tokyo and the other regions of Japan are markedly different. Figures 1 and 2 show the proportion of outputs from Tokyo and from the other regions, respectively, and illustrate the characteristics of the economic structure of the industrial sectors of the different regions (TMG 2007). The total production value of Tokyo is about 165 trillion yen, while that of other regions is about 836 trillion yen. The major industrial activities in Tokyo are concentrated in the tertiary sector. The production value of the "civil services and service industry" sectors of Tokyo amounted to about 58 trillion yen, which is approximately $35 \%$ of the total production value of Tokyo. In the original classification of the 197 industrial sectors in the IRWIOT, "advertising, survey and information services" amounted to 10 trillion yen and was the largest activity among those in the "civil services and service industry" sector. In the second largest sector, i.e., "commerce", the largest activity was "financial and insurance", at 12 trillion yen.

In other regions, the major industrial activities were related to the "manufacturing and construction" sector, which accounted for $43 \%$ of the total production value of the other regions shown in Fig. 2. Around $74 \%$ of the intermediate outputs from the "manufacturing and construction" sector of other regions, which is equivalent to approximately 137 trillion yen, was consumed by the "manufacturing and construction" sectors themselves. The production value of "other cars", "public construction", "building construction" and

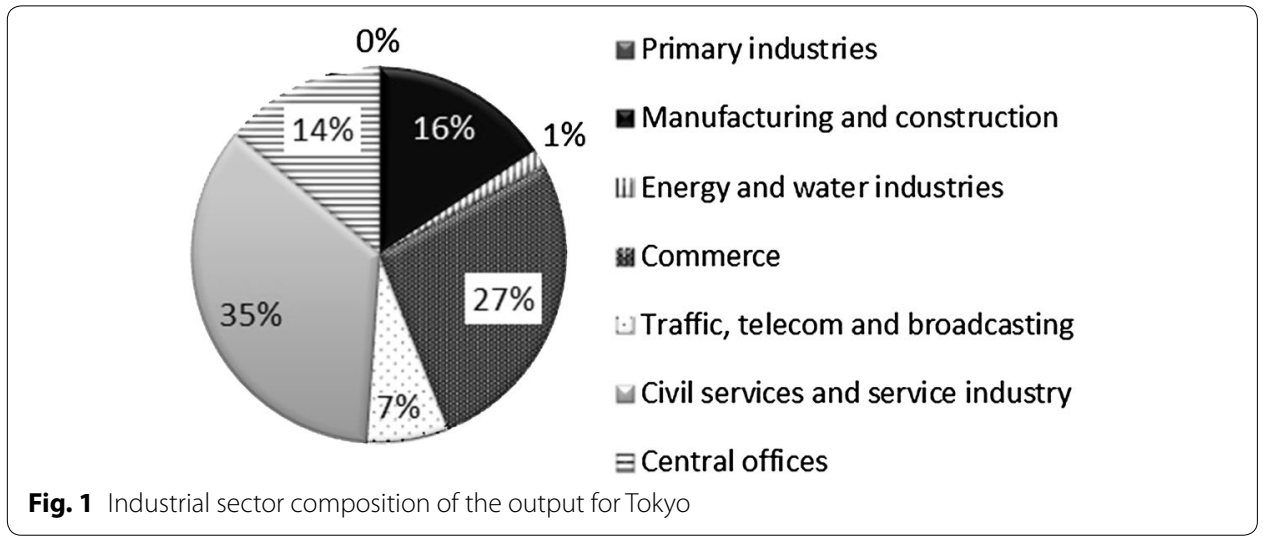

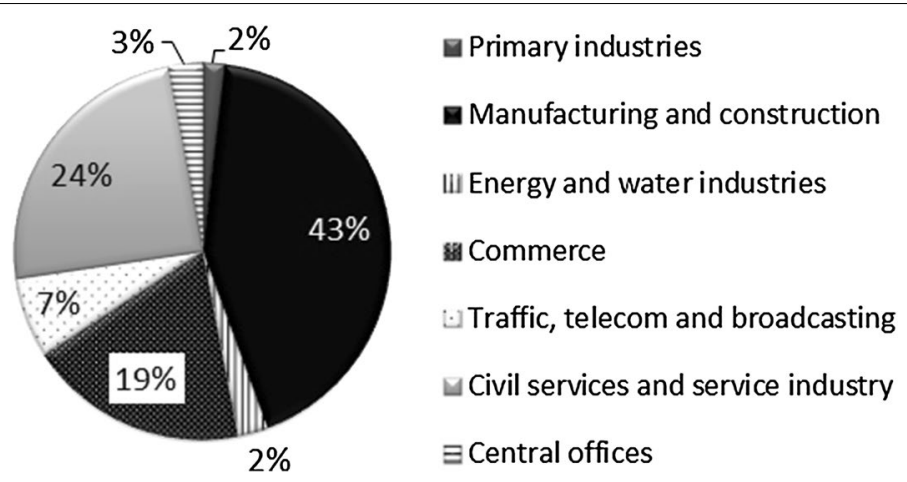

Fig. 2 Industrial sector composition of the output for other regions in Japan 
"foods" accounted for the largest proportion of total production in the "manufacturing and construction" sectors of other regions.

Within the context of industrial structure, consumer spending trends in Tokyo and in other regions were more similar. The final demand of Tokyo amounted to 70 trillion yen, which was equivalent to about $14 \%$ of the domestic final demand of Japan. Consumption by the residents of Tokyo accounted for approximately half of the final demand of Tokyo, which was 32 trillion yen. Consumption by the residents of other regions accounted for about 236 trillion yen. In both regions, consumers primarily spent their cash on goods and services in tertiary industries, such as "house rent", "retail trade", "eating and drinking", "finance and insurance" and "education"; together, these expenses accounted for over $70 \%$ of total consumption. In Tokyo, $26 \%$ of consumption was for "house rent" (including imputed house rent), which was larger than that in other regions where it only accounted for $20 \%$; this difference is due to land prices in Tokyo being the highest in Japan. Imputed house rent refers to virtual house rent because this house expense is treated as an asset in the IO framework and not as part of consumption. Consumption in the "food" sector was similar between regions, but the residents of Tokyo were highly dependent upon the food industries in other regions. Indeed, more than approximately $71 \%$ of consumption in the "food" sector of Tokyo was imported from other regions.

\subsection{Dependence of Tokyo on other religions for waste treatment}

The composition of waste items differed markedly between Tokyo and the other regions. Based on generation source, industrial and business wastes are both generated by the industrial sectors, and household waste is generated by the final demand sectors. In Tokyo, 16 million tons of waste is generated annually; this waste comprises industrial waste (66 \%), business waste (16\%) and household waste (18\%). However, in other regions, the 350 million tons of waste that is generated annually comprises 81,7 and $12 \%$ for the same categories, respectively. These findings show that the proportion of industrial waste in other regions is considerably larger than that of Tokyo, and reflects the marked differences that exist in the industrial structure of Tokyo and other regions (MOE 2003a, b, 2004). As mentioned previously, the main industries in Tokyo are tertiary industries which generate relatively less industrial waste than business waste.

Further, the waste generated by the industrial sectors in Tokyo and in the other regions is also different, especially for the proportion by waste category. Figure 3 shows the proportion of industrial waste by type in Tokyo and the other regions. The amount of industrial waste generated in Tokyo is approximately 11 million tons, while that generated in other regions is approximately 285 million tons. In Tokyo, the largest proportion of industrial waste is "sludge", which accounts for 6 million tons, followed by "construction and demolition wastes" at over 3 million tons. Construction activities generate sludge, and activities such as tearing down buildings generate "construction and demolition waste", such as rubble and scrap wood. In other regions, "construction and demolition waste" is also large, but "livestock excreta" accounts for 91 million tons (32\%), corroborating the finding that primary industries are more important in other regions than in Tokyo, as shown in Figs. 1 and 2. It is worth noting that more than half of the industrial waste generated in Tokyo was transported to other regions for treatment. 


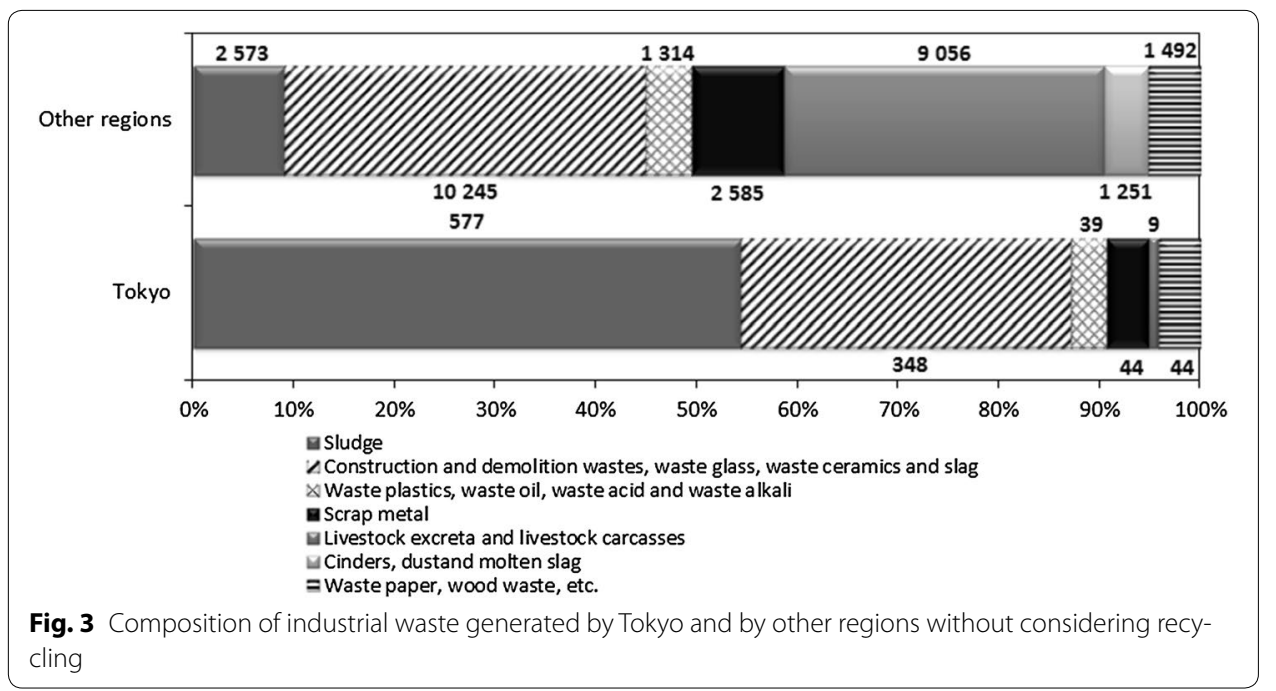

Industrial sectors not only generate wastes, but they also recycle them as part of their production activities. Figure 4 shows the composition of net generation of waste (i.e., total waste generated excluding the recycling of industrial waste) in Tokyo and other regions. The net generation of waste in Tokyo amounted to approximately 7 million tons, implying that about $37 \%$ of the industrial waste produced in Tokyo was recycled, which is considerably less than that of other regions where the amount of waste produced, considering recycling, was 48 million tons or $83 \%$. However, the recycling rate of "construction and demolition waste" in Tokyo was about $92 \%$, which contributed markedly to reduce the amount of waste that needed to be treated materially (TMG 2012). In other regions, the amount of scrap metal in the table was a negative value, implying

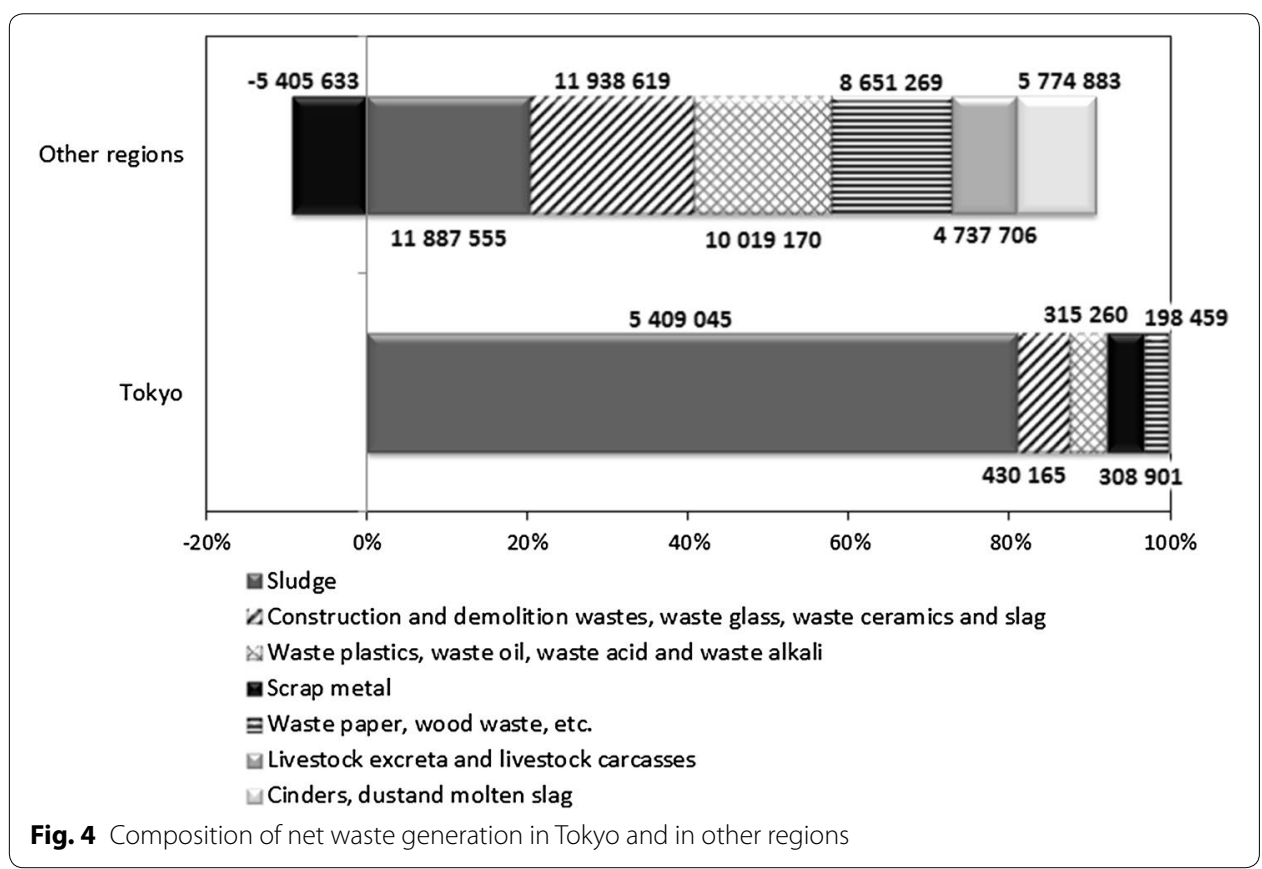


that the amount of scrap metal generated was less than the amount of scrap metal that was recycled and transported to other countries. Most of the "construction and demolition wastes" generated in other regions were also recycled. "Construction and demolition wastes" were recycled as construction material or base course material. Inorganic sludge was recycled in the cement sector (Ministry of Land, Infrastructure, Transport and Tourism 2005). Livestock excreta and livestock carcasses were typically recycled to produce organic fertilizer. Organic sludge was also recycled as fertilizer.

According to the Tokyo 2000 IRWIO table compiled in this study, the quantity of MSW generated was markedly less than industrial waste. The amount of business waste generated in Tokyo and in other regions was about 3 million tons and 23 million tons, respectively, while the amount of MSW household waste generated in Tokyo and in other regions was about 3 million tons and 42 million tons, respectively. The composition of MSW business waste in Tokyo and in the other regions was similar. The largest waste category was "waste paper and waste textiles" which accounted for around $50 \%$ in both regions, followed by "food waste" (25\%), "waste plastics" (10\%), "waste metal" (5\%), "bottle and waste" (4\%) and "other" (5\%). However, the composition of household waste in both regions was different. In Tokyo, food waste amounted to 1.1 million tons, or $38 \%$ of the total waste in Tokyo, which was considerably larger than the 8.3 million tons, or $20 \%$, generated in other regions. These results appeared to contradict the finding in subsection 3.1, which stated that consumption in the "food" sector was similar between Tokyo and the other regions. However, the proportion of single-person households in Tokyo was about $41 \%$, which is much higher than the approximately $26 \%$ found in other regions (Statistics Bureau of MIC 2012). Since single-person households generate about 1.5 times more waste per person than households with more than two people (Oikawa et al. 2000), the composition of household size is considered to have a marked effect on the amounts of household food waste generated in Tokyo and in other regions.

Since the populations and number of households in Tokyo and in the other regions differ considerably, we divided the quantity of MSW generated by the number of households in each region, as shown in Fig. 5.

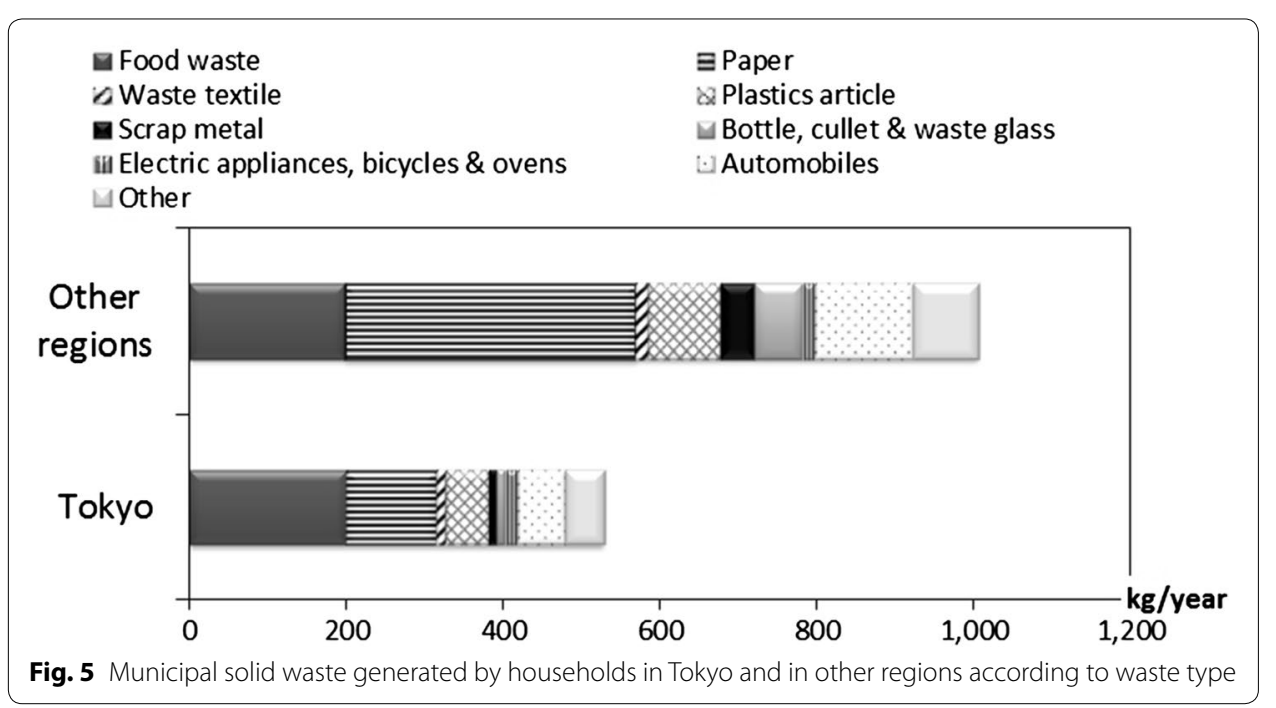


The amount of household-produced MSW in Tokyo is about $528 \mathrm{~kg}$ per household, which is approximately half of the $1004 \mathrm{~kg}$ of MSW produced per household in other regions. As mentioned in Sect. 1, it is extremely difficult to construct new landfills in Tokyo. Consequently, compared to most of the municipalities in the other regions, the municipalities of Tokyo have enthusiastically promoted initiatives directed at reducing and/or recycling waste. These initiatives are the main reason for the observed differences in the amounts of MSW produced in Tokyo compared to the other regions.

The amount of "paper" that is disposed of per annum in Tokyo and in the other regions is $114 \mathrm{~kg}$ and $369 \mathrm{~kg} /$ year per person, respectively. In Tokyo, the collection of waste paper by private companies is becoming a serious social problem (Yamamoto 2005). In Japan, MSW is typically processed by the municipalities within each prefecture, and in Tokyo, households dispose of their MSW by placing it at centralized points for collection by municipal vehicles. By recycling some of this waste, municipalities are able to recover part of the costs incurred by waste collection. However, private companies have begun "snatching" this waste paper, which has the effect of increasing the financial burden associated with waste collection by municipalities. In addition, this "snatched" paper cannot subsequently be considered in waste statistics. In a densely populated metropolitan region such as Tokyo, the collection of waste paper by these illegal private operators accounts for the disparity observed in the amount of paper waste generated by individual households in Tokyo and in other regions.

Another waste category that differs between Tokyo and other regions is automobiles. The most important factor affecting the generation of automobile waste is ownership per household, which was $58 \%$ in Tokyo and $115 \%$ in other regions in 2000 (Automobile Inspection \& Registration Information Association 2000). Since public modes of transport, such as trains, subways and buses, are extremely well developed in Tokyo, the need for an automobile is considerably lower than it is in other regions.

Thus, differences in the types of waste between Tokyo and other regions were primarily related to the differences in the living environment and lifestyles of the residents of these regions.

\subsection{Effect of consumption by Tokyo residents}

Consumption in Tokyo increased economic activity in both Tokyo and other regions. As shown in Table 3, about 50 trillion yen of goods and services are induced by Tokyo residents. The total value of production induced by Tokyo was approximately 33 trillion yen, while that induced by other regions was only about 16 trillion yen. In Tokyo, most of the induced production could be attributed to tertiary industries, such as "commerce" (16 trillion yen) and "civil services and service industry" (10 trillion yen). "house rent" was the largest of these induced production values, accounting for 8 trillion yen, followed by "retail trade" and "finance and insurance". The induced production value of "manufacturing and construction", which tends to generate large amounts of waste, was about 2 trillion yen and that attributable to "primary industries" was only 36 billion yen. The induced production value in other regions was mainly attributable to goods and services in the "manufacturing and construction" sector ( 9 trillion yen), and in the "primary industries" sector (1 trillion yen). The largest induced production value in the industrial sector was in the "food industry" (1.8 trillion yen), followed by "wholesale trade" (1.5 
Table 3 Repercussion effects of consumption by Tokyo residents as direct, indirect and total effects on goods and services sectors

\begin{tabular}{|c|c|c|c|c|c|c|}
\hline \multirow[t]{2}{*}{ Region } & \multirow[t]{2}{*}{ Industry } & \multirow{2}{*}{$\begin{array}{l}\text { Direct effects } \\
\text { (Consumption } \\
\text { of residents } \\
\text { in Tokyo) }\end{array}$} & \multicolumn{3}{|c|}{ Indirect effects } & \multirow[t]{2}{*}{ Total effects } \\
\hline & & & Tokyo & Other regions & Total & \\
\hline \multirow[t]{7}{*}{ Tokyo } & Primary industries & 73,229 & 168,676 & 921 & 169,598 & 412,424 \\
\hline & $\begin{array}{l}\text { Manufacturing } \\
\text { and construction }\end{array}$ & $2,137,314$ & $1,510,264$ & 80,500 & $1,590,764$ & $5,318,842$ \\
\hline & $\begin{array}{l}\text { Energy and water } \\
\text { industries }\end{array}$ & 813,165 & 405,307 & 0 & 405,307 & $1,623,780$ \\
\hline & Commerce & $13,658,967$ & $2,045,671$ & 233,914 & $2,279,585$ & $18,218,137$ \\
\hline & $\begin{array}{l}\text { Traffic, telecom } \\
\text { and broadcast- } \\
\text { ing }\end{array}$ & $2,211,737$ & 906,843 & 47,284 & 954,127 & $4,119,990$ \\
\hline & $\begin{array}{l}\text { Civil services and } \\
\text { service industry }\end{array}$ & $7,174,910$ & $2,520,362$ & 259,329 & $2,779,692$ & $12,734,293$ \\
\hline & Central offices & 0 & 810,568 & 369,447 & $1,180,015$ & $2,360,030$ \\
\hline \multirow[t]{7}{*}{ Other regions } & Primary industries & 378,220 & 207,261 & $1,121,418$ & $1,328,679$ & $3,035,578$ \\
\hline & $\begin{array}{l}\text { Manufacturing } \\
\text { and construction }\end{array}$ & $4,251,424$ & $1,730,734$ & $3,540,969$ & $5,271,703$ & $14,794,830$ \\
\hline & $\begin{array}{l}\text { Energy and water } \\
\text { industries }\end{array}$ & 87,400 & 63,726 & 266,482 & 330,208 & 747,815 \\
\hline & Commerce & 724,863 & 252,863 & $1,054,818$ & $1,307,681$ & $3,340,225$ \\
\hline & $\begin{array}{l}\text { Traffic, telecom } \\
\text { and broadcast- } \\
\text { ing }\end{array}$ & 358,880 & 235,918 & 661,456 & 897,373 & $2,153,627$ \\
\hline & $\begin{array}{l}\text { Civil services and } \\
\text { service industry }\end{array}$ & 33,247 & 297,177 & 957,293 & $1,254,471$ & $2,542,188$ \\
\hline & Central offices & 0 & 785,367 & 361,437 & $1,146,804$ & $2,293,607$ \\
\hline Value added & & - & $21,419,106$ & $7,497,100$ & $28,916,207$ & $\begin{array}{l}57,832,413 \\
\text { (million yen) }\end{array}$ \\
\hline
\end{tabular}

trillion yen). The induced production values of Tokyo were greater than those of other regions in almost all industries except "primary industries" and "manufacturing and construction", which tended to generate large amounts of industrial waste, as shown in Table 4.

The impact of consumption by Tokyo residents on value added was similar to that of production value, although the results show that the benefit to other regions was actually lower than it was for Tokyo. Specifically, the total induced added value in the other regions only amounted to 7 trillion yen, while the total induced added value for Tokyo was more than three times that in other regions. These findings show that while consumption in Tokyo did stimulate economic activities in the other regions, those benefits were markedly less than the benefits to Tokyo. Further, the benefits mainly affected the industrial sectors whose waste generation coefficients were considerably larger than those of the service industries.

Estimates of the effect of consumption by Tokyo residents on greenhouse gas emissions revealed that consumption by Tokyo residents had an undesirable effect on both Tokyo and on the other regions. The total amount of $\mathrm{CO}_{2}$ emissions in other regions was about 14 million $\mathrm{CO}_{2}$-tons, which is similar to that observed in Tokyo. The $\mathrm{CO}_{2}$ emissions induced by "manufacturing and construction" in other regions were approximately 
Table 4 Waste induced by consumption in Tokyo considering recycling

\begin{tabular}{|c|c|c|c|c|c|c|c|}
\hline Region & Industry & $\begin{array}{l}\text { Waste } \\
\text { generation } \\
\text { (ton) }\end{array}$ & $\begin{array}{l}\text { Recycling } \\
\text { waste } \\
\text { inputs (ton) }\end{array}$ & $\begin{array}{l}\text { Waste } \\
\text { generation } \\
\text { consider- } \\
\text { ing recy- } \\
\text { cling (ton) }\end{array}$ & $\begin{array}{l}\mathrm{CO}_{2} \\
\text { emission } \\
\left(\mathrm{t}-\mathrm{CO}_{2}\right)\end{array}$ & $\begin{array}{l}\text { Landfill } \\
\text { volume } \\
\left(\mathrm{m}^{3}\right)\end{array}$ & $\begin{array}{l}\text { Landfill } \\
\text { area }\left(\mathrm{m}^{2}\right)\end{array}$ \\
\hline \multirow[t]{8}{*}{ Tokyo } & $\begin{array}{l}\text { Primary } \\
\text { industries }\end{array}$ & 43,561 & 0 & 43,561 & 16,647 & - & - \\
\hline & $\begin{array}{l}\text { Manufactur- } \\
\text { ing and } \\
\text { construc- } \\
\text { tion }\end{array}$ & 695,581 & 192,727 & 502,854 & 429,270 & - & - \\
\hline & $\begin{array}{l}\text { Energy and } \\
\text { water } \\
\text { industries }\end{array}$ & 59,158 & 714 & 58,445 & $7,152,954$ & - & - \\
\hline & Commerce & 420,697 & 0 & 420,697 & 367,713 & - & - \\
\hline & $\begin{array}{l}\text { Traffic, tel- } \\
\text { ecom and } \\
\text { broadcast- } \\
\text { ing }\end{array}$ & 30,146 & 0 & 30,146 & $3,416,815$ & - & - \\
\hline & $\begin{array}{l}\text { Civil services } \\
\text { and } \\
\text { service } \\
\text { industry }\end{array}$ & 373,581 & 0 & 373,581 & $1,114,870$ & - & - \\
\hline & $\begin{array}{l}\text { Central } \\
\text { offices }\end{array}$ & 52,792 & 0 & 52,792 & 0 & - & - \\
\hline & $\begin{array}{l}\text { Waste treat- } \\
\text { ment }\end{array}$ & 121,031 & 0 & 121,031 & 688,985 & 862,355 & 431,178 \\
\hline \multirow[t]{8}{*}{$\begin{array}{l}\text { Other } \\
\text { regions }\end{array}$} & $\begin{array}{l}\text { Primary } \\
\text { industries }\end{array}$ & $7,865,458$ & 31 & $7,865,426$ & 515,107 & - & - \\
\hline & $\begin{array}{l}\text { Manufactur- } \\
\text { ing and } \\
\text { construc- } \\
\text { tion }\end{array}$ & $2,624,680$ & $10,363,938$ & $-7,739,258$ & $6,661,652$ & - & - \\
\hline & $\begin{array}{l}\text { Energy and } \\
\text { water } \\
\text { industries }\end{array}$ & 269,862 & 873 & 268,990 & $3,656,291$ & - & - \\
\hline & Commerce & 154,386 & 1088 & 153,299 & 66,300 & - & - \\
\hline & $\begin{array}{l}\text { Traffic, tel- } \\
\text { ecom and } \\
\text { broadcast- } \\
\text { ing }\end{array}$ & 139,175 & 308 & 138,867 & $2,547,419$ & - & - \\
\hline & $\begin{array}{l}\text { Civil services } \\
\text { and } \\
\text { service } \\
\text { industry }\end{array}$ & 156,615 & 660 & 155,955 & 95,083 & - & - \\
\hline & $\begin{array}{l}\text { Central } \\
\text { offices }\end{array}$ & 309,464 & 58,972 & 250,491 & 0 & - & - \\
\hline & $\begin{array}{l}\text { Waste treat- } \\
\text { ment }\end{array}$ & 18,232 & 0 & 18,232 & 296,662 & $1,087,748$ & 543,874 \\
\hline
\end{tabular}

6.7 million $\mathrm{CO}_{2}$-tons, which are more than 16 times that of Tokyo. This was likely due to the "pig iron" and "petroleum refinery products" sectors in other regions which emitted 1425 thousand $\mathrm{CO}_{2}$-tons and 1265 thousand $\mathrm{CO}_{2}$-tons, respectively. Of these two emission sources, the $\mathrm{CO}_{2}$ emission coefficients associated with pig iron are considerable. As mentioned in subsection 3.1, the main industries in Tokyo are tertiary industries. Not surprisingly, therefore, the average $\mathrm{CO}_{2}$ emission coefficient for Tokyo was only 0.37 $\left(\mathrm{CO}_{2}\right.$-tons/million yen), while it is $0.82\left(\mathrm{CO}_{2}\right.$-tons/million yen) in other regions. 
Thus, although consumption in Tokyo increased economic activity in both Tokyo and in the other regions, this increase in economic activity led to increases in $\mathrm{CO}_{2}$ emissions. Consequently, the effect of consumption in Tokyo on other regions tends to be more undesirable than it is desirable.

As the economic activities in both regions were stimulated by Tokyo residents, large amounts of industrial waste were generated in both regions. Figure 6 shows the total amounts of "industrial waste" and MSW (i.e., "household waste" and "business waste") that were induced by consumption by Tokyo residents. In Tokyo, 759,000 tons of business waste was induced by consumption by Tokyo residents, which is about 2.4 times larger than that in other regions. Conversely, more industrial waste (1.4 million tons) was induced in other regions, which is almost twice that induced by Tokyo. As shown in Fig. 6, the impact of "household waste" is negative because the amount of "household waste" that was recycled in both Tokyo and in other regions was larger than the amount of household waste that was generated. The increase in production activities, which is influenced by Tokyo resident consumption, has the effect of increasing the inputs of recycled waste, especially "household waste" in both Tokyo and in other regions. Waste paper is the most widely recycled waste, 645,000 tons of which is recycled by "paper and paperboard" industry. Other wastes, such as "waste glass", "waste textiles" and "waste plastics", were also recycled in industrial sectors, such as "beverages", "glass and glass products", "textile products" and "plastic products", respectively. Consumption in Tokyo contributed to a reduction in the amount of "household waste" that needs to be treated and that was inputted as recycled waste to industrial sectors. However, in this study, the increase in the total amount of waste generated in Tokyo was 1.5 million tons, while that of other regions increased by 1.1 million tons. Despite the recycling activities in industrial sectors, the amount of waste generated by most of the industrial sectors was markedly larger than that of recycled waste.

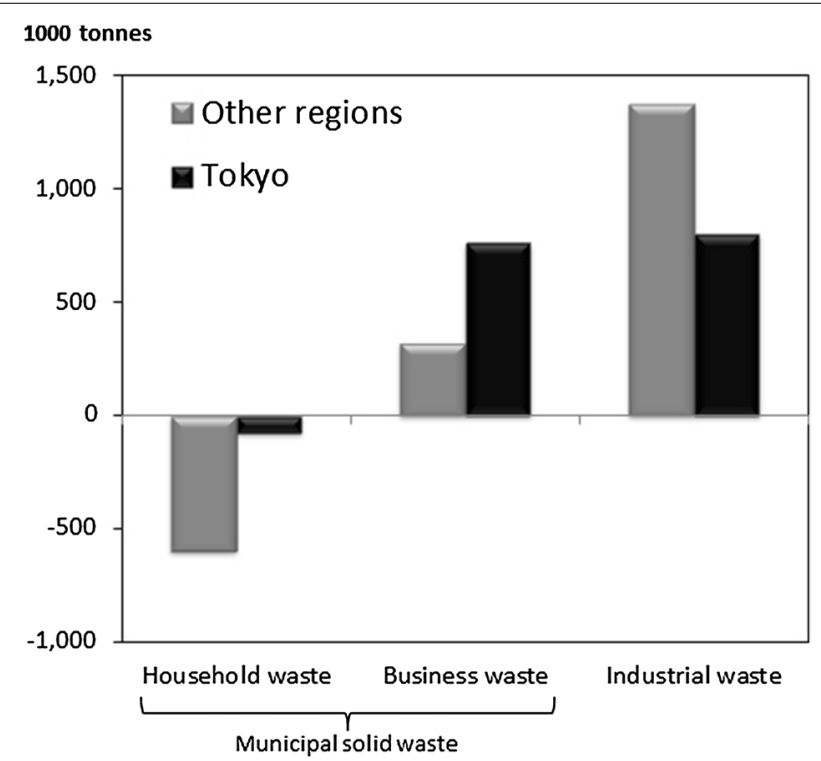

Fig. 6 Net amount of waste induced by Tokyo residents 
As shown in Table 5, the waste induced by consumption in Tokyo, considering recycling, accounted for 451,000 tons of "sludge", followed by 364,000 tons of "waste paper and waste textiles", 233,000 tons of "food waste", and 179,000 tons of "construction and demolition wastes, waste glass, ceramics, slag". Most of the sludge was generated by the "foods" and "publishing, printing" sectors. In other regions, induced waste consisted primarily of 939,000 tons of "construction and demolition wastes, waste glass, ceramics, slag". The sectors "waste paper and waste textiles", "waste oil, waste acid, waste alkali, waste plastics" and "cinders, dust, molten slag" accounted for 286,000, 253,000, and 205,000 tons, respectively.

When considering the transportation of waste between Tokyo and the other regions, the environmental burden assumed by the other regions was considerably larger than that incurred by Tokyo. Although Tokyo accepted very little waste from the other regions, Tokyo exported large amounts of waste to the other regions. Figure 7 shows the industrial waste generated by Tokyo; of this total, 353,000 tons (approx. 24 \%) of all industrial wastes generated in Tokyo was transported and treated in other regions.

Table 6 shows the five largest industrial sectors in terms of wastes exported from Tokyo to other regions, and the amounts and types of transported waste. Together, these wastes accounted for $93 \%$ of the total amount of transported waste. Of the different types of waste transported to other regions, considerably more construction sludge was transported than any of the other waste categories.

Of the large amounts of waste that were induced by Tokyo consumption and then transported to other regions, large quantities of residues were landfilled in other regions after treatment by intermediate waste treatment facilities. Figure 8 shows the amount of induced waste that needed to be landfilled. Consumption by Tokyo residents typically induced large amounts of waste for landfilling and decreased the landfill capacity of regions outside Tokyo. Even if we consider the desirable effects of recycling MSW, Tokyo still required about 1.1 million $\mathrm{m}^{3}$ of landfill volume in other regions due to

Table 5 Waste induced by consumption in Tokyo considering recycling

\begin{tabular}{lcc}
\hline Waste categories & Tokyo & Other regions \\
\hline Household waste & $-35,711$ & $-505,154$ \\
Waste paper and waste textile & $-1,581$ & $-17,012$ \\
Waste plastics & $-39,190$ & $-76,332$ \\
Waste bottles and waste ceramics & 124,723 \\
Business waste & 93,169 \\
Food waste & 233,395 \\
Waste paper and waste textile & 363,860 \\
Others & 161,541 \\
Industrial waste & 98,961 \\
Sludge & 451,279 \\
Waste oil, waste acid, waste alkali, waste plastics & 61,687 \\
Waste paper, wood waste, fibers waste, animal and vegetable residue, waste rubber & 52,940 \\
Scrap metal & 18,840 \\
Construction wastes, waste glass, waste ceramics, slag & $-78,155$ \\
Livestock excreta, livestock corpses & 179,043 \\
Cinders, dust, molten slag & 939,031 \\
\hline
\end{tabular}




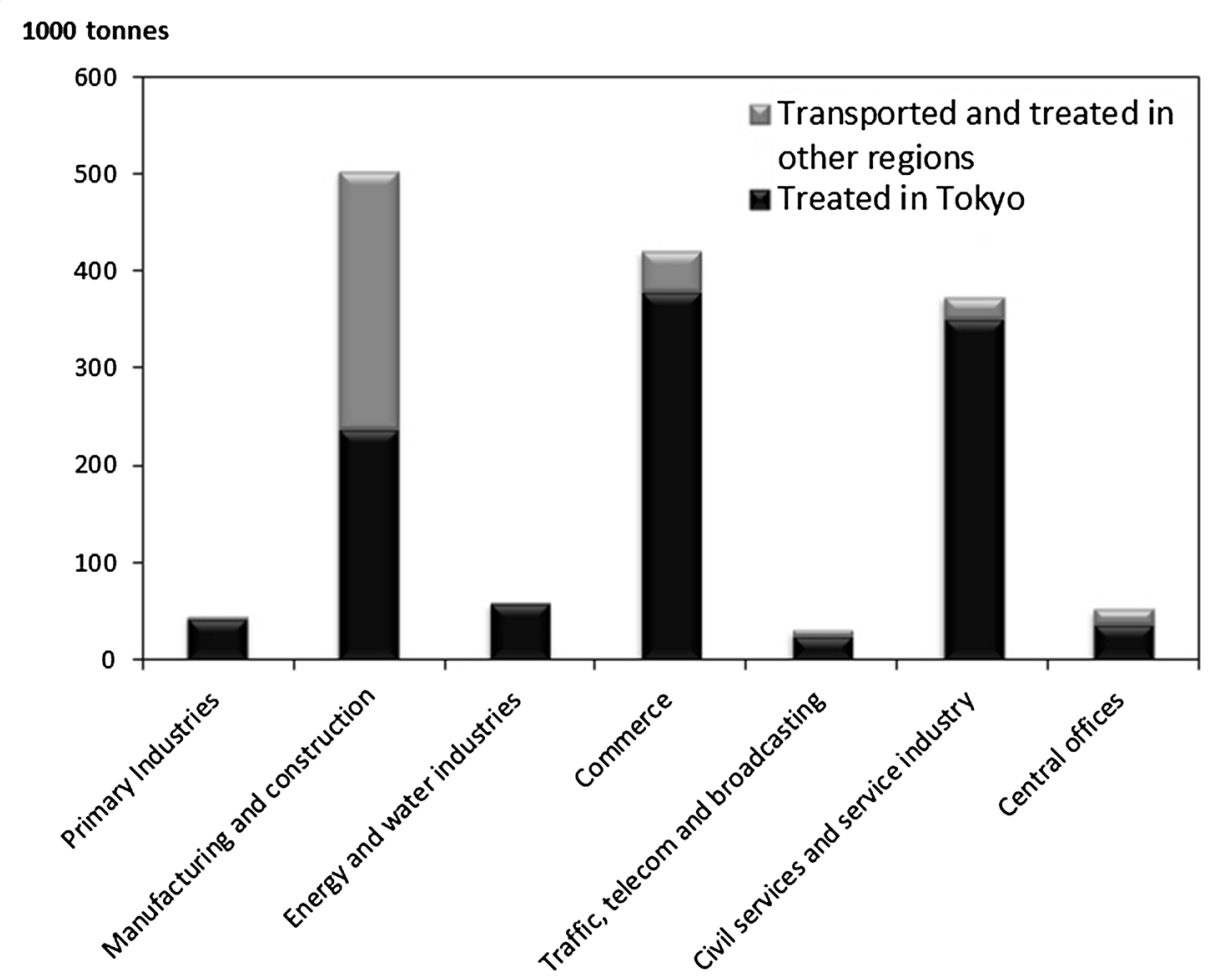

Fig. 7 Amount of induced industrial waste that is transported from Tokyo

Table 6 Main industrial sectors with large amounts of transported waste

\begin{tabular}{|c|c|c|c|c|c|}
\hline & 12 & 23 & 24 & 85 & 87 \\
\hline Thousand tons & Foods & $\begin{array}{l}\text { Paper } \\
\text { products }\end{array}$ & $\begin{array}{l}\text { Publishing } \\
\text { and printing }\end{array}$ & $\begin{array}{l}\text { Miscellaneous } \\
\text { manufacturing } \\
\text { products }\end{array}$ & $\begin{array}{l}\text { Repair } \\
\text { of construction }\end{array}$ \\
\hline $\begin{array}{l}\text { Construction } \\
\text { sludge }\end{array}$ & 0.0 & 0.0 & 0.0 & 0.0 & 216.7 \\
\hline Waste oil & 7.9 & 0.0 & 0.2 & 0.0 & 0.8 \\
\hline Waste plastics & 0.9 & 0.1 & 0.8 & 0.7 & 2.9 \\
\hline Waste paper & 0.0 & 6.9 & 4.9 & 0.0 & 1.8 \\
\hline Wood waste & 5.0 & 0.0 & 0.0 & 0.3 & 5.6 \\
\hline $\begin{array}{l}\text { Animal and vegeta- } \\
\text { ble residues }\end{array}$ & 7.4 & 0.0 & 0.0 & 0.1 & 0.0 \\
\hline Iron scraps & 0.0 & 0.0 & 0.0 & 0.1 & 10.0 \\
\hline
\end{tabular}

Italic values indicate the sectors that the amounts of transported waste are significantly large

consumption by its residents. Since the landfill volume in Tokyo is equivalent to approximately 0.9 million $\mathrm{m}^{3}$, the burden placed upon the other regions was approximately 1.3 times greater than the burden within Tokyo. The landfill volume induced per household by metropolitan consumption in other regions was approximately $0.201 \mathrm{~m}^{3} /$ year, which is considerably more than the $0.159 \mathrm{~m}^{3} /$ year induced per household in Tokyo. In addition, the large amounts of industrial waste (e.g., "construction sludge") that are also transported to these regions from Tokyo are landfilled, further increasing the burden on these regions. 


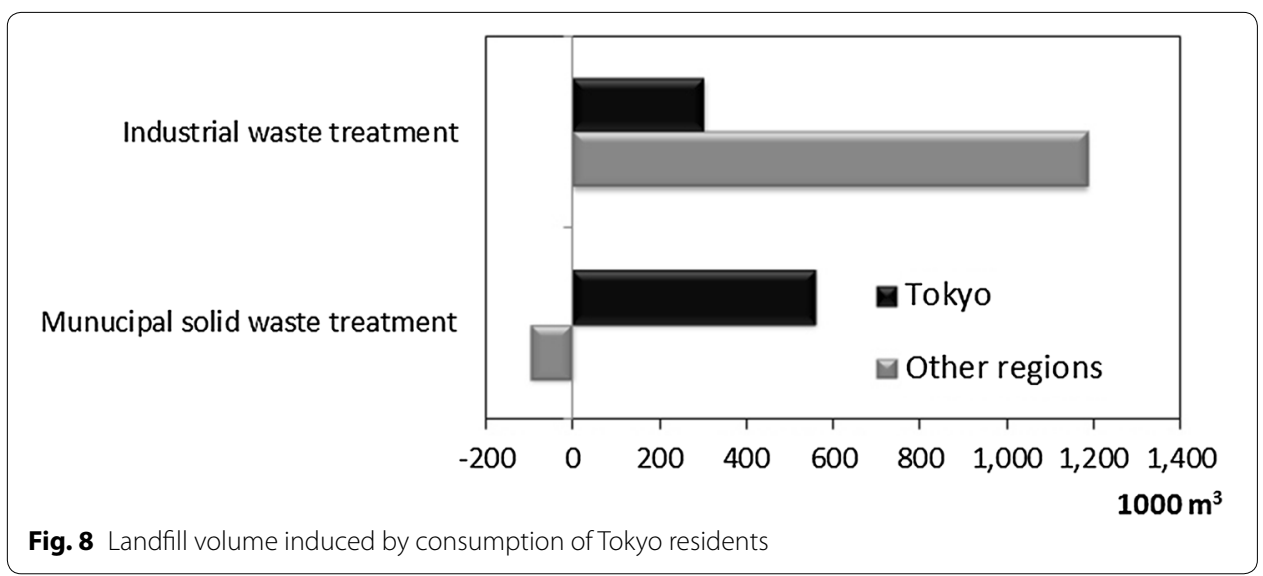

\section{Conclusions}

We compiled an interregional WIO table for Tokyo in the year 2000 and evaluated the effect of consumption by the metropolitan region on other regions using the table. The results showed that the consumption activities in Tokyo induced fewer economic benefits in the regions outside Tokyo, while markedly increasing the induced environmental loads in these regions, especially the utilization of landfills. Although consumption by Tokyo residents promoted production activities in other regions, the value of that induced production in industrial sectors was only half as much as that in Tokyo, and the value added was only about third that of Tokyo. Moreover, the final demand of Tokyo consumption generated almost the same amount of $\mathrm{CO}_{2}$ in the other regions as in Tokyo. Although economic benefits were induced by Tokyo consumption, the associated burden on other regions due to Tokyo consumption was considerable. In developing waste treatment policies, it is important to conduct quantitative investigations of the waste treatment efficiency of an entire country, as well as to determine how to share responsibility between regions. As such, Tokyo should assume more responsibility for the additional environmental loads in other regions, especially considering the volume of landfill that it uses.

One of the ways in which this responsibility could be shared more equitably between the metropolitan regions and other regions is to levy taxes for interregional waste treatment and landfill utilization. In Japan, the decision of whether or not to impose such landfill taxes would be up to individual prefectures. Previous studies on landfill taxes in Japan mainly evaluated the effectiveness of those taxes on waste reduction in each prefecture (Kurasaka 2003; Nagasaki 2003; Fujioka and Hagihara 2007; Sasao 2014). In this study, we were able to quantitatively demonstrate that Tokyo depends, both directly and indirectly, on other regions for waste transportation and waste treatment. These results highlighted the importance of the interdependent relationships that exist between regions, such as Tokyo and the other regions, as well as the need to consider the indirect effects of these interdependent economic relationships and how this information can be used to formulate more effective waste treatment policies between regions. Future research will involve detailed regional analyses of the interdependent relationships that exist among the 46 prefectures in Japan, excluding Tokyo, within the context of waste treatment at a national scale. 
Another potentially effective solution is to encourage recycling. As we demonstrated in this study, if economic activities are stimulated by consumption in metropolitan regions, then the increase in recycled wastes will reduce the amount of waste that needs to be treated. Concerted efforts by Japan to reduce landfill waste have reduced the rate of landfilling of industrial waste by $10 \%$ to just $3 \%$ in 15 years (MOE Japan 2001a, 2012a, 2014 a). About $55 \%$ of all industrial waste generated is recycled, and $42 \%$ of that is processed by waste treatment. The results of this study showed that $30 \%$ of the induced waste in Tokyo is generated by the construction industry, indicating that waste reduction and recycling of "construction and demolition wastes" are still important. In other regions, the recycling rate of slag from "publishing, printing" also needs to be improved to reduce the amount of waste that needs to be processed in those areas. Unlike the recycling rates for industrial waste, the average recycling rate for MSW in Japan is only $20.6 \%$, which is about $10 \%$ less than it was 15 years previously (MOE Japan 2001b, 2012b, 2014b). The study also demonstrated the importance of improving MSW recycling rates, particularly in the business waste categories of "food waste" and "waste cardboard" from industries such as "retail trade" and "eating and drinking places" in Tokyo, as the amount of induced waste in these categories is large in Tokyo.

We demonstrated that the economic activities of Tokyo are mainly centered on tertiary industries. These activities are associated with high levels of consumption, which increase the environmental loads of other regions, particularly in the areas to which the resulting waste is transported, treated and landfilled. Importantly, the economic benefits induced by metropolitan consumption activities in Tokyo were smaller in other regions than they were in Tokyo. Using the methodology developed in this study, the interdependence between economic activities and environmental loads between regions can be quantitatively analyzed (Additional file 1).

\section{Additional file}

Additional file 1: Table S1. Tokyo $2000 \mathrm{IRWIO}$ table. Table S2. Allocation Matrix. Table S3. Detailed results of the direct effects. Table S4. Detailed results of the indirect effects.

Authors' contributions

SK, YK and MT developed the methodology. MT was in charge of data collection and carried out the calculation and generated the quantitative results. MT, SK and YK interpreted the results and drew the conclusions. All authors read and approved the final manuscript.

Author details

${ }^{1}$ Faculty of Commerce, Tokyo International University, 1-13-1, Matoba-kita, Kawagoe, Saitama 350-1197, Japan. ${ }^{2}$ Faculty of Economics, Kyushu University, 6-10-1, Hakozaki, Higashi-ku, Fukuoka 812-8581, Japan. ${ }^{3}$ Faculty of Political Science and Economics, Waseda University, 1-6-1 Nishiwaseda, Shinjuku-ku, Tokyo 169-8050, Japan.

\section{Acknowledgements}

"Survey Results of Transportation and Recycling of Waste" data were kindly supplied by Mr. Kazuaki Inoue of the Ministry of the Environment of Japan. Financial support for this study was obtained in the form of an annual subsistence grant from Tokyo International University.

Competing interests

The authors declare that they have no competing interests.

\section{Appendix: Compilation of the international import coefficient matrix}

The TMG table is a two-region, interregional, non-competitive import-type input-output table, the transaction of goods and services within region $r$ includes international imports to region $r$, which is indicated by $\mathbf{Z}_{\mathbf{I}}^{\mathbf{r r}}+\mathbf{Z}_{\mathbf{I}}^{\mathbf{3 r}}$ (Table 1). The consumption of goods 
and services in region $r$ by the residents of region $s$, and other final demands in region $s$ for goods and services in region $r$ which also included international imports to region $r$, can be represented as $\mathbf{f}_{\mathbf{C}}^{\mathbf{r r}}+\mathbf{f}_{C}^{3 \mathbf{r}}$ and $\mathbf{f}_{O}^{\mathbf{r r}}+\mathbf{f}_{O}^{3 \mathbf{r}}$, respectively.

The international import coefficient matrix $\overline{\mathbf{M}}^{\mathbf{r}}$ can, therefore, be defined as shown in Eq. (8) below, if $i=j$ and $i, j=1, \ldots, n_{\mathrm{X}} ; r=1,2$ :

$$
\bar{m}_{i j}^{r}=\frac{\mathbf{M}^{\mathbf{r}}(\mathbf{i})}{\sum_{j=1}^{n_{x}}\left(\mathbf{Z}_{\mathbf{I}}^{\mathbf{r r}}(\mathbf{i}, \mathbf{j})+\mathbf{Z}_{\mathbf{I}}^{\mathbf{3 r}}(\mathbf{i}, \mathbf{j})\right)+\mathbf{f}_{\mathbf{C}}^{\mathbf{r r}}(i)+\mathbf{f}_{\mathbf{C}}^{3 \mathbf{r}}(i)+\mathbf{f}_{\mathbf{O}}^{\mathbf{r r}}(i)+\mathbf{f}_{\mathbf{O}}^{3 \mathbf{r}}(i)}
$$

where $\bar{m}_{i j}^{r}$ is the diagonal element of $\overline{\mathbf{M}}^{\mathbf{r}}$. If $i \neq j, \bar{m}_{i j}^{r}$ is 0 . In this study, we assumed that the transaction volume of international imports is proportional to the demand of each region, and the international trade of waste was assumed to be determined exogenously. $\mathbf{Z}_{\mathbf{I}}^{\mathbf{r r}}, \mathbf{Z}_{\mathbf{I}}^{3 \mathbf{r}}, \mathbf{f}_{\mathbf{C}}^{\mathbf{r r}}, \mathbf{f}_{O}^{\mathbf{r r}}, \mathbf{f}_{C}^{\mathbf{3 r}}$ and $\mathbf{f}_{O}^{3 \mathbf{r}}$ in the IRWIO table in this study can thus be estimated from the TMG table using $\overline{\mathbf{M}}^{\mathbf{r}}$, as shown in Eqs. (9-14) below.

$$
\begin{aligned}
& \mathbf{Z}_{\mathbf{I}}^{\mathbf{r r}}=\left(\mathbf{I}-\overline{\mathbf{M}}^{\mathbf{r}}\right)\left(\mathbf{Z}_{\mathbf{I}}^{\mathbf{r r}}+\mathbf{Z}_{\mathbf{I}}^{3 \mathbf{r}}\right) \\
& \mathbf{Z}_{\mathbf{I}}^{3 \mathbf{r}}=\overline{\mathbf{M}}^{\mathbf{r}}\left(\mathbf{Z}_{\mathbf{I}}^{\mathbf{r r}}+\mathbf{Z}_{\mathbf{I}}^{3 \mathbf{r}}\right) \\
& \mathbf{f}_{\mathbf{C}}^{\mathbf{r r}}=\left(\mathbf{I}-\overline{\mathbf{M}}^{\mathbf{r}}\right)\left(\mathbf{f}_{\mathbf{C}}^{\mathbf{r r}}+\mathbf{f}_{\mathbf{C}}^{3 \mathbf{r}}\right) \\
& \mathbf{f}_{\mathbf{C}}^{3 \mathbf{r}}=\overline{\mathbf{M}}^{\mathbf{r}}\left(\mathbf{f}_{\mathbf{C}}^{\mathbf{r r}}+\mathbf{f}_{\mathbf{C}}^{3 \mathbf{r}}\right) \\
& \mathbf{f}_{\mathbf{O}}^{\mathbf{r r}}=\left(\mathbf{I}-\overline{\mathbf{M}}^{\mathbf{r}}\right)\left(\mathbf{f}_{\mathbf{O}}^{\mathbf{r r}}+\mathbf{f}_{\mathbf{O}}^{3 \mathbf{r}}\right) \\
& \mathbf{f}_{\mathbf{C}}^{3 \mathbf{r}}=\overline{\mathbf{M}}^{\mathbf{r}}\left(\mathbf{f}_{\mathbf{O}}^{\mathbf{r r}}+\mathbf{f}_{\mathbf{O}}^{3 \mathbf{r}}\right)
\end{aligned}
$$

Received: 15 December 2014 Revised: 27 January 2015 Accepted: 9 September 2015 Published online: 12 October 2015

References

Automobile Inspection \& Registration Information Association (AIRIA) (2000) Statistical Data of Number of Automobiles in Japan. http://www.airia.or.jp/number/index.html. Accessed 31 March 2000

Bicknell KB, Ball RJ, Cullen R, Bigsby HR (1998) New methodology for the ecological footprint with an application to the New Zealand economy. Ecol Econ 27:149-160

Bureau of Environment, (TMG) (2003) Survey Report of Annual Change of Industrial Waste in Tokyo 2000

Bureau of Environment, TMG (2012) Current status of industrial waste. (http://www.kankyo.metro.tokyo.jp/resource/ industrial_waste/about_industrial_waste/about_03/index.html). Accessed 7 March 2012

Bureau of Environment, Tokyo Metropolitan Government (TMG) (2001) Tokyo Metropolitan Government Environmental White Paper 2000, pp 123-130, http://www.kankyo.metro.tokyo.jp/basic/plan/white_paper/backnumber/2000. html. Accessed 20 March 2007

Cazcarro I, Duarte R, Sánchez-Chóliz J (2013) Water footprints for Spanish regions based on a multi-regional input-output (MRIO) model. In: Murray J, Lenzen M (eds) The sustainability practitioner's guide to multi-regional input-output analysis. Common Ground, Champaign, pp 119-132

Clean Association of TOKYO23 (2001) Measurement results of waste property findings for 2000

Daniels PL, Lenzen M, Kenway SJ (2011) The ins and outs of water use -a review of multi-region input-output analysis and water footprints for regional sustainability analysis and policy. Econ Syst Res 23:353-370

Feng K, Siu YL, Guan D, Hubacek K (2012) Assessing regional virtual water flows and water footprints in the Yellow River Basin, China: a consumption based approach. Appl Geogr 32:691-701 
Fry J, Lenzen M (2014) Constructing a multi-regional waste input-output framework using Australian waste, 22nd IIOA Conference. https://www.iioa.org/conferences/22nd/papers/files/1515.pdf. Accessed 1 June 2015

Fujioka S, Hagihara K (2007) A study on the effects of industrial waste taxes - the case of Mie Prefecture (in Japanese). Stud Reg Sci 37:89-101

Guan D, Hubacek K (2007) Assessment of regional trade and virtual water flows in China. Ecol Econ 61:159-170

Habara H, Matsuto T, Tanaka N (2002) estimation model for commercial waste stream by type of business activities. J J.jpn Soc Waste Manage Expert 13:315-324

Hasegawa R, Kagawa S, Tsukui M (2011) The carbon footprint and carbon leakage of prefectures: a case study of Japan. http://www.iioa.org/files/conference-2/385.pdf. Accessed 10 August 2013

Hertwich EG (2011) The life cycle environmental impacts of consumption. Econ Syst Res 23:27-47

Isard W (1951) Interregional and regional input-output analysis: a model of a space economy. Rev Econ Stat 33:318-328

Kagawa S, Nakamura S, Inamura H, Yamada M (2007) Measuring spatial repercussion effects of regional waste management. Resour Conserv Recycl 51:141-174

Kagawa S, Kondo Y (2007) Regional waste input-output analysis, input-output life cycle analysis. In: Nakamura S (eds) Lifecycle input-output analysis (in Japanese). Waseda University, Tokyo, pp105-140

Kurasaka H (2003) Trends and points for local taxes on industrial wastes in Japan (in Japanese). Jpn Soc Mater Cycles Waste Manage 14:171-181

Lenzen M (2009) Understanding virtual water flows: a multiregion input-output case study of Victoria. Water Resour Res 45:1-11

Lenzen M, Moran D, Kanemoto K, Foran B, Lobefaro L, Geschke A (2012) International trade drives biodiversity threats in developing nations. Nature 486:109-112

Lenzen M, Murray SA (2001) A modified ecological footprint method and its application to Australia. Ecol Econ 37:229-255

Lenzen M, Pade L, Munksgaard J (2004) CO $\mathrm{CO}_{2}$ multipliers in multi-region input-output models. Econ Syst Res 16:391-412

Lenzen M, Reynolds CJ (2014) A supply-use approach to waste input-output analysis. J Ind Ecol 18:212-226

Leontief W (1963) The structure of development. Sci Am 209:148-166

López-Morales C, Duchin F (2011) Policies and technologies for a sustainable use of water in Mexico: a scenario analysis. Econ Syst Res 23:387-407

Matsuto T (2005) Toshi-Gomi Syori system no Bunseki, Keikaku, Hyouka (analysis, planning and assessment of municipal solid waste). Gihodo Shuppan Co. Ltd, Tokyo (in Japanese)

McGregor P, Glen P, Swales JK, Turner K (2008) The $\mathrm{CO}_{2}$ 'trade balance' between Scotland and the rest of the UK: Performing a multi-region environmental input-output analysis with limited data. Ecol Econ 66:662-673

Ministry of Economy, Trade and Industry of Japan (METI) (2002) 2000 Census of manufactures. http://www.meti.go.jp/ statistics/tyo/kougyo/library/index.html. Accessed 19 January 2010

Ministry of Finance, Government of Japan (2000) 2000 Trade statistics. http://www.customs.go.jp/toukei/download/ index_d211_e.htm. Accessed 27 August 2008

Ministry of Land, Infrastructure, Transport and Tourism (2005) Current state of the construction by-product; recycling website of MLIT. http://www.mlit.go.jp/sogoseisaku/region/recycle/fukusanbutsu/genjo/index.htm. Accessed 10 December 2005

Minx JC, Wiedmann T, Wood R, Peters GP, Lenzen M, Owen A, Scott K, Barrett J, Hubacek K, Baiocchi G, Paul A, Dawkins E, Briggs J, Guan D, Suh S, Ackerman F (2009) Input-output analysis and carbon footprinting: an overview of applications. Econ. Syst. Res. 21:187-216

MOE Japan (2001a) 1998 Survey Results of industrial waste generation and treatment. http://www.env.go.jp/recycle/ waste/sangyo/sangyo h10.pdf. Accessed 9 August 2015

MOE Japan (2001b) 1998 Survey results of general waste generation and treatment. http://www.env.go.jp/recycle/ waste_tech/ippan/h10/index.html. Accessed 9 August 2015

MOE Japan (2003a) 2000 Survey Results of MSW Treatment. http://www.env.go.jp/recycle/waste_tech/ippan/h12/index. html. Accessed 15 February 2010

MOE Japan (2003b) 2000 Survey results of industrial waste generation and treatment. Electronic data obtained from MOE Library

MOE Japan (2004) 2003 Survey results of transportation and recycling of waste. Electronic data obtained from MOE Library

MOE Japan (2012a) 2010 The survey results of industrial waste facility. http://www.env.go.jp/recycle/waste/kyoninka/ h22chosa.pdf. Accessed 13 August 2013

MOE Japan (2012b) 2010 The survey results of MSW treatment. http://www.env.go.jp/recycle/waste_tech/ippan/h22/ index.html. Accessed 24 March 2012

MOE Japan (2014a) 2012 Survey results of industrial waste generation and treatment. http://www.env.go.jp/recycle/ sangyo_h24a.pdf. Accessed 9 August 2014

MOE Japan (2014b) 2012 Survey results of general waste generation and treatment. http://www.env.go.jp/recycle/ waste_tech/ippan/h25/data/env_press.pdf. Accessed 9 August 2014

Nagasaki T (2003) Establishment of Industrial waste tax and the current status after its enforcement (in Japanese). Jpn Soc Mater Cycles Waste Manage 14:202-208

Nakamura S, Kondo Y (2002) Input-output analysis of waste management. J Ind Ecol 6:39-64

Nakamura S, Kondo Y (2009) Waste input-output analysis: concepts and application to industrial ecology. Springer, NY

Nakamura S (2010) Waste input-output table Japan 2000 (WIO2000) version 0.06. http://www.f.waseda.jp/nakashin/ wio_j.htm. Accessed 10 January 2010

Nansai K, Moriguchi Y, Touno S (2008) Embodied energy and emission intensity data for Japan using input-output tables. http://www.cger.nies.go.jp/publications/report/d031. Accessed 27 December 2010

New Energy and Industrial Technology Development Organization (NEDO) (2005) Report on Research and Development on the LCA for Products and LCA for End-of-life Stage (in Japanese), pp 408-426 
Nijdam DS, Wilting HC, Goedkoop MJ, Madsen J (2005) Environmental load from Dutch private consumption how much damage takes place abroad? J Ind Ecol 9:147-168

Oikawa T, Mimor K, Tanikawa N (2000) Survey of waste generation sources, Tokyo Metropolitan Research Institute Annual Report, pp 23-41

Peters GP (2008) From production-based to consumption-based national emission inventories. Ecol Econ 65:13-23

Peters GP, Hertwich EG (2006a) Pollution embodied in trade: the Norwegian case. Glob Environ Change 16:379-387

Peters GP, Hertwich EG (2006b) The importance of imports for household environmental impacts. J Ind Ecol 10:89-109

Peters GP, Hertwich EG (2008) Post-Kyoto greenhouse gas inventories: production versus consumption. Clim Change 86:51-66

Reynolds CJ, Piantadosi J, Boland J (2014) A waste supply-use analysis of Australian waste flows. J Econ Struct 3:5. doi:10.1186/s40008-014-0005-0

Reynolds CJ, Boland J, Thompson KR (2012) The creation of a dual waste and multi regional input-output model for Australian conditions, 20th International Input-output Association Conference, 24-29 June, Bratislava Slovakia. http://www.iioa.org/conferences/20th/papers/files/825_20120518071_PaperReynoldsMRWIO.pdf. Accessed 10 August 2013

Sasao T (2004) An estimation of the social costs of landfill siting using a choice experiment. Waste Manag 43:188-218

Sasao T (2014) Does industrial waste taxation contribute to reduction of landfilled waste? Dynamic Panel analysis considering industrial waste category in Japan. Waste Manag 34:2239-2250

Statistics Bureau of MIC of Japan (2004) 2000 Input-output tables for Japan. http://www.stat.go.jp/english/data/io/io00. htm. Accessed 1 March 2004

Statistics Bureau of MIC of Japan (2012) Statistics of Japan 2012. http://www.stat.go.jp/data/nihon/index1.htm. Accessed 14 August 2012

Statistics Bureau of MIC of Japan (2014) Population estimates by age and sex 2014. http://www.e-stat.go.jp/SG1/estat/ ListE.do?lid=000001120061. Accessed 22 July 2014

Statistics Bureau of Ministry of Internal Affairs and Communications (MIC) of Japan (2000) 1999 Establishment and enterprise census. http://www.stat.go.jp/english/data/jigyou/index.htm. Accessed 12 February 2008

Tokyo Metropolitan Government (TMG) (2008) The basic environmental plan 2008. http://www.kankyo.metro.tokyo.jp/ basic/plan/master_plan/summary_2/index.html. Accessed 31 March 2008

Tokyo Metropolitan Government (TMG) (2011) In order to properly handle industrial waste. http://www.kankyo.metro. tokyo.jp/resource/industrial_waste/on_waste/properly_processed.html. Accessed 1 April 2011

Tokyo Metropolitan Government (TMG) (2012) Report of industrial waste for the change of each year 2011, Tokyo Metropolitan Government (TMG)

Tokyo Metropolitan Government Bureau of General Affairs (2007) The interregional input-output table Tokyo 2000. http://www.toukei.metro.tokyo.jp/sanren/2000/sr00t1.HTM. Accessed 1 April 2007

Tsukui M (2007a) Analysis of structure of waste emission in Tokyo by interregional waste input-output table, 11 th International Waste Management and Landfill Symposium Italy, Sardinia

Tsukui M (2007b) LCA of garbage disposal for household use by interregional waste input-output analysis. J Life Cycle Assess Jpn 3:212-220

Tsukui M (2008) The technical considerations in the compilation method of interregional waste input-output table (in Japanese). J Life Cycle Assess Jpn 4:334-348

Tsukui, M (2009) The Interregional waste transportation model for the compilation of interregional waste input-output table, International Society for Industrial Ecology, 5th International Conference on Industrial Ecology Calouste Gulbenkian Foundation, Lisbon, Portugal, pp 69

Tsukui M, Nakamura K (2009) Modeling of waste transportation for the estimation of energy consumptions and $\mathrm{CO}_{2}$ emissions by multiple means of transportation. J. Life Cyc. Assess. Jpn. 5:462-472

Tsukui M, Kagawa S, Kondo Y (2011a) Analysing the environmental repercussion effects of metropolitan consumption activities: an interregional waste input-output approach, ISIE 2011 Conference, University of California, Berkeley, 7-10 June 2011

Tsukui M, Kagawa S, Kondo Y (2011b) Impacts of final consumptions in Tokyo on productions and environmental loads in other regions: an interregional waste input-output approach. J Life Cycle Assess Jpn 8:2012

Turner K, Lenzen M, Wiedmann T, Barrett J (2007) Examining the global environmental impact of regional consumption activities-Part 1: a technical note on combining input-output and ecological footprint analysis. Ecol Econ 62:37-44

Weber CL, Matthews HS (2007) Embodied environmental emissions in U.S. international trade, 1997-2004. Env Sci Tech 41:4875-4881

Weber CL, Matthews HS (2008) Quantifying the global and distributional aspects of American household carbon footprint. Ecol Econ 66:379-391

Wiedmann T (2009) A review of recent multi-region input-output models used for consumption-based emission and resource accounting. Ecol Econ 69:211-222

Wiedmann T, Lenzen M, Turner K, Barrett J (2007) Examining the global environmental impact of regional consumption activities_-Part 2: review of input-output models for the assessment of environmental impacts embodied in trade. Ecol Econ 61:15-26

Wiedmann T, Minx J, Barrett J, Wackernagel M (2006) Allocating ecological footprints to final consumption categories with input-output analysis. Ecol Econ 56:28-48

Wiedmann TO, Schandl H, Lenzen M, Moran D, Suh S, West J, Kanemoto K (2013) The material footprint of nations. Proc Natl Acad Sci USA. http://www.pnas.org/content/early/2013/08/28/1220362110 (Published online before print)

Wilting HC, Vringer K (2009) Carbon and land use accounting from a producer's and a consumer's perspective-an empirical examination covering the world. Econ. Syst. Res. 21:291-310

Yamamoto K (2005) CLOSE UP advanced and unique ordinance: anti-snatch of used paper law, Jichitai Houmu Kenkyu (Research of Municipal Legal Affairs) (In Japanese), 3, 11, pp 44-49 
Yi I, Itsubo N, Inaba A, Matsumoto K (2007) Development of the interregional I/O based LCA method considering regionspecifics of indirect effects in regional evaluation. Int J Life Cycle Assess 12:353-364

Zaman AU, Lehmann S (2011) Urban growth and waste management optimization towards 'zero waste city'. City Cult Soc 2:177-187

Submit your manuscript to a SpringerOpen ${ }^{\circ}$ journal and benefit from:

- Convenient online submission

- Rigorous peer review

- Immediate publication on acceptance

- Open access: articles freely available online

- High visibility within the field

- Retaining the copyright to your article

Submit your next manuscript at $>$ springeropen.com 